\title{
High level of perceived stress among essential workers during the COVID 19 lockdown in a Nigerian state
}

\author{
*Falade J. ${ }^{1}$, Oshatimi A.M. ${ }^{2}$, Oyebanji A.H. ${ }^{3}$, Babatola A.O. ${ }^{4}$, Fadare J.O. ${ }^{5}$, Olatunya O.S. ${ }^{4}$ \\ Falade 0.0. ${ }^{6}$
}

\begin{abstract}
Background: COVID-19 pandemic caused unexpected socio-economic changes globally. This study determined the prevalence and factors associated with perceived stress among essential workers during the COVID-19 lockdown in Ekiti State, Nigeria.
\end{abstract}

Method: A cross-sectional descriptive study that involved 588 essential workers in Ekiti State, Nigeria during the COVID-19 lockdown. The Perceived Stress Scale was used in the study Chi-square test of statistical significance and multivariate analysis using binary logistic regression were used in the analysis and the level of statistical significance was determined by a p-value of $<0.05$.

Results: The prevalence of high perceived stress levels among all the respondents, health workers, and non-health workers were $64.1 \%$ (63.3-70.6), while health workers and non-health workers had a prevalence of $70.1 \%(65.5-73.3)$ and $56.5 \%(23.5-38.7)$ respectively. The majority of the respondents related their sources of stress to inadequate transportation (63.3\%), hearing of COVID related news (47.4\%), and lack of finance (55.1\%). Using Logistic Regression respondent respondents who were not satisfied with the support they received from the government during the pandemic had three fold high stress levels than respondents who were satisfied with the support received from the government [AOR= 3.228, $(\mathrm{CI}=1.771-5.886)]$. Furthermore, the odd of the high stress level was one fold increased among male respondents than female respondents $[\mathrm{AOR}=1.08 \mathrm{CI}=(1.410-6.215)$.

Conclusion: Stress management is recommended given the high-stress level among essential workers.

Keywords; COVID 19; Essential workers; lockdown; High Perceived Stress; Ekiti State; Nigeria

\author{
*Corresponding author \\ Falade J. \\ ORCID-NO: http://orcid.org/0000-0002-6612-0705 \\ falade.joshua@abuad.edu.ng
}

${ }^{1}$ Department of Mental Health, Afe Babalola University, Ado-Ekiti, Nigeria

${ }^{2}$ University Health Center, Federal University of Oye-Ekiti, Oye-Ekiti, Nigeria

${ }^{3}$ Department of Pediatrics, Afe Babalola University, Ado-Ekiti, Nigeria

${ }^{4}$ Department of Pediatrics, Ekiti State University, Ado Ekiti, Nigeria

${ }^{5}$ Department of Clinical Pharmacology / Internal Medicine Ekiti State University, Ado Ekiti, Nigeria

${ }^{6}$ Osun State School of Nursing, Asubiaro, Osogbo, Nigeria 


\title{
Niveau de stress perçu chez les travailleurs essentiels pendant le casanier du COVID-19 dans l'état d'Ekiti, au Nigéria
}

\author{
*Falade J. ${ }^{1}$, Oshatimi A.M. ${ }^{2}$, Oyebanji A.H. ${ }^{3}$, Babatola A.O. ${ }^{4}$, Fadare J.O. ${ }^{5}$, Olatunya O.S. ${ }^{4}$ \\ Falade 0.0. ${ }^{6}$
}

\section{Résumé}

Contexte général de l'étude : La pandémie de COVID-19 a provoqué des changements socioéconomiques inattendus dans le monde. Cette étude a déterminé la prévalence et les facteurs liés au stress perçu à un niveau parmi les travailleurs essentiels pendant la période de confinement du COVID-19 dans l'état d'Ekiti, au Nigéria.

Méthode de l'étude : Une étude descriptive transversale qui a impliqué 588 travailleurs essentiels dans l'état d'Ekiti, au Nigéria, dans le cadre du confinement COVID-19. L'échelle de stress perçu a été utilisée dans le test du Chi carré de l'étude et une analyse multi variée a été utilisée. Le niveau statistiquement significatif a été déterminé par une valeur $\mathrm{p}<0,05$.

Résultats de l'étude: Le total des répondants non-agents de santé et agents de santé présentait une prévalence de niveaux élevés de stress perçu de $64,1 \%(63,3-70,6), 56,5 \%(23,5-38,7)$ et $70,1 \%(65,5$ $73,3)$. La majorité des répondants ont lié leurs sources de stress à un transport inadéquat $(63,3 \%)$, à l'audition de nouvelles liées à COVID $(47,4 \%)$ et au manque de financement $(55,1 \%)$ En utilisant la régression logistique, les répondants qui étaient insatisfaits du soutien gouvernemental pendant la pandémie avaient des niveaux de stress trois fois plus élevés que les répondants qui étaient insatisfaits du soutien gouvernemental $[\mathrm{AOR}=3.228,(\mathrm{IC}=1.771-5.886)]$. De plus, l'impair du niveau de stress élevé était un fois plus élevé chez les hommes interrogés que chez les femmes [AOR $=1,08 \mathrm{IC}=(1,410-6,215)$.

Conclusion : La gestion du stress est recommandée étant donné le niveau de stress élevé chez les travailleurs essentiels.

Mots-clés : COVID-19, travailleurs essentiels, confinement; stress perçu élevé, état d'Ekiti, Nigéria

\author{
*Corresponding author \\ Falade J. \\ ORCID-NO: http://orcid.org/0000-0002-6612-0705 \\ falade.joshua@abuad.edu.ng \\ ${ }^{1}$ Department of Mental Health, Afe Babalola University, Ado-Ekiti, Nigeria \\ ${ }^{2}$ University Health Center, Federal University of Oye-Ekiti, Oye-Ekiti, Nigeria \\ ${ }^{3}$ Department of Pediatrics, Afe Babalola University, Ado-Ekiti, Nigeria \\ ${ }^{4}$ Department of Pediatrics, Ekiti State University, Ado Ekiti, Nigeria \\ ${ }^{5}$ Department of Clinical Pharmacology / Internal Medicine Ekiti State University, Ado Ekiti, Nigeria \\ ${ }^{6}$ Osun State School of Nursing, Asubiaro, Osogbo, Nigeria
}

Research Journal of Health Sciences subscribed to terms and conditions of Open Access publication. Articles are distributed under the terms of Creative Commons Licence (CC BY-NC-ND 4.0). (http://creativecommons.org/licences/by-nc-nd/4.0).

http://dx.doi.org/10.4314/rejhs.v9i4.3 


\section{INTRODUCTION}

The global spread of coronavirus disease 2019 (COVID-19) has caused unexpected and significant changes to the lives of the populace (1). COVID-19 was first reported in China in December 2019 and declared a pandemic in March 2020 by the World Health Organization (2). COVID-19 caught the world unprepared (3). Since the first confirmed case in Africa, then there has been a steady rise in the number of diseases in Africa due to the high volume of business and tourism between Europe and Africa. A Nigerian study reported the case fatality rate (CFR), prevalence rate, and mortality of COVID19 to be $2.26 \%, 0.015 \%$, and $0.00034 \%$ respectively (4).

During the COVID 19 pandemic, the government declared total lockdown as one of the global strategies for curbing the menace and that people should work from home. However, some workers who by virtue of their jobs cannot render services from home. These sets of workers are know as Essential Workers. They are recognized as workers who must discharge their duties and so should not be affected by movement restrictions. These workers include health workers, security officers, senior government officers, and social workers

In the setting of a global pandemic, it is normal to be frightened for one's safety (and potential mortality), particularly with data emerging about airborne and fomite transmission, exposure risk from asymptomatic carriers, limited testing, and well-publicized issues regarding conflicting advice about what level of personal protective equipment (PPE) is necessary or available. The negative socioeconomic and political impacts of the pandemic have generated a lot of worry for people leading to increased levels of psychological disorders (5).

Front-line key workers, such as healthcare providers and non-healthcare related staff (e.g. social workers and law enforcement agents,) are important in reducing the effect of the COVID-19 pandemic. Globally, there are numerous risk factors for psychological illness among essential workers (6). In Italy, lack of specific resources, such as a lack of beds in Intensive Care Units, essential medicines and ventilators, fear of being quarantined, and increased demand on the health systems, were risk factors for psychological illness among health workers (7).

Perceived stress level is important in the determination of clinician wellness (8). It can impact negatively on patient's care and lead to increased medical errors, malpractice risk, and early retirement. Greater clinician stress may lead to greater rates of drug and alcohol addiction, divorce, and suicide (1). A recent survey revealed a burnout (stress) rate of 35\% among United States allergy and immunology physicians $(1,9)$. A study from China reported that healthcare workers and frontline workers had higher psychological stress compared to the general public during the COVID-19 pandemic; this elevated psychological stress was associated with the respondents' perception of their health and infection risks (10). Another study from Saudi Arabia found that health workers were at greater risk of psychological distress than nonhealth workers (2).

Surges of COVID- 19 cases are likely to aggravate stress among doctors and nurses particularly in developing countries where their health systems are already stressed (11). This problem may be compounded by a significant shortage of personal protective types of equipment (PPE), predisposing the health workers to a high risk of transmission. An Indian study among health care workers reported that one-half and two-thirds of their respondents feared contracting and trasnsmitting COVID-19 infection respectively (12).

Nigeria is plagued with the recurrent crisis of non-payment, delayed payment as well as salary cuts of workers both essential and nonessential workers (13). While other workers were asked to stay at home during the lockdown, he essential workers were required to attend to the basic needs of societal living.

Understanding the psychological impact of the COVID-19 outbreak among essential workers is crucial in guiding policies and interventions to maintain their psychological well-being. There is a dearth of information on the level of perceived stress among essential workers in Nigeria during the COVID 19 lockdown in the year 2020

This study, therefore set out to assess the prevalence and factors associated with perceived stress levels among essential workers in Ekiti State, Nigeria. Also, this study aimed to determine sources of stress among essential workers during the lockdown.

Null Hypothesis: There will be no significant increase in perceived stress among Health Care workers compared to Non-Health Care workers during the COVID 19 Lockdown in Ekiti State Nigeria 


\section{MATERIALS AND METHODS}

\section{Study settings, participants, and design}

This was a cross-sectional descriptive study involving essential workers in Ekiti State, Nigeria during the COVID-19 lockdown. Ekiti State has three senatorial districts and six federal constituencies. Essential workers include health care workers (doctors, nurses, and medical laboratory scientists), security personnel (army, police, local security outfits), financial sector workers (bankers, accountants), COVID-19 monitoring committees, senior political office holders, and senior civil servants.

\section{Sample Size}

Using the Sample size table from The Research Advisors a minimum sample of 384 (95\% Confidence Interval and 5\% precision) was optimally estimated for a population parameter (14). Five hundred and ninety-six questionnaires were received between April and July 2020.

A convenience sampling method was employed and the study participants were contacted from the lists generated by various Head of Departments and the questionnaires were sent to them online through their WhatsApp numbers) and responses sent back to the investigators. There were eight questionnaires with missing data that were removed from the analysis.

Inclusion criteria: All essential workers on duty in Ekiti state, Nigeria who gave consent to participate in the study.

Exclusion criteria: Essential workers who were on leave or were not assigned to work during the COVID 19 lockdown.

\section{Study Instruments}

The questionnaires were structured and comprised two sections

(1) The Socio-Demographic and psychological variable - This section contained information on the sociodemographic profiles of respondents which included age, gender, marital status, occupation, religion, family structure, and tribe. Psychological variables include the previous history of psychological disorders, family history of psychological disorders, satisfaction with the government during the COVID 19 lockdown, and satisfaction with the organization

(2) Perceived Stress Scale (PSS): The perceived stress scale (PSS) was used. It is a measure of the degree to which circumstances in one's life are assessed as stressful. Items were designed to identify how impulsive, overwhelming, and overloaded respondents find their lives. The PSS was designed for use in community samples with at least a junior high school education. Moreover, the questions are general and hence are relatively free of content specific to any sub-population group. The questions in the PSS ask about feelings and thoughts during the last month. In each case, respondents are asked how often they felt a certain way (15). Cronbach's coefficient of reliability for the PSS was 0.86 and 0.636 in Nigeria studies $(16,17)$.

The scale has 10 questions that determine the degree to which situations in one's life are appraised as stressful. Each respondent chooses from the following alternatives: 0 marks for never, 1 mark for seldom, 2 marks- sometimes, 3 marks fairly often, and 4 marks very often. The marks are added together with the minimum and maximum obtainable scores are being 0 and 40 .

Questions number 4, 5, 7, and 8 were reversed during the scoring. In this study respondents whose scores range from zero to thirteen were classified as Low stress, fourteen to twenty-six as moderate stress, and twenty-seven to forty as high stress (18).

\section{Statistical Analysis}

The Statistical Product and Service Solutions (SPSS version 23) was used for Data analysis. The socio-demographic details of respondents were reported using descriptive statistics such as frequency, means, and standard deviation (SD). A Chi-square test was used to determine the relationship between perceived stress and the socio-demographic variables. The binary logistic regression was used to identify the factors that are significantly associated with perceived stress among the study participants. The confidence interval was set at $95 \%$ and all tests were two-tailed. Statistical significance was considered a p-value less than 0.05 .

Ethics: Ethical approval was obtained from the Research Ethics Committee of the Ekiti State University Ado Ekiti and a letter of permission was given to heads of various institutions. Online written Consent was obtained from the individual respondent. 


\section{RESULTS}

Socio-demographic characteristics of the respondents

Five hundred and eighty-eight questionnaires were completed and returned, Table 1 shows the socio-demographic characteristics of respondents. Above average $(56.1 \%)$ of the respondents were $\leq 35$ years, males $(67.5 \%)$, Christians $(85.7 \%)$, health workers $(73.5 \%)$, married $(71.9 \%)$, and from Yoruba ethnicity (82.5\%). About three-quarters significant proportion of the respondents $(74.5 \%)$ earn Two hundred and fifty thousand naira (\#250,000) or less per month,

\section{Psychological Characteristics of the respondents}

One hundred and thirty-six (23.1\%) had a previous history of psychological disorder while $5.3 \%$ of the respondents had a family history of psychological disorder. the majority (72.4\%) were not satisfied with the support they received from the government during the lockdown, while $80.6 \%$ of the respondents were not satisfied with the support they received from their organization during the lockdown.

\section{Sources of Stressors among essential workers during the COVID-19 lockdown}

The majority of the respondents related their sources of stress to inadequate transportation $(63.3 \%)$, hearing of COVIDrelated news $(47.4 \%)$, and lack of finance (55.1\%) (Table 2).

\section{Prevalence of Stress High Level among the Respondents}

The prevalence of high-stress level among the respondents was $64.1 \%$ (63.3-70.6), while health workers and non-health workers had a prevalence of $70.1 \%(65.5-73.3)$ and $56.5 \%$ (23.5-38.7) respectively (Figure 1)

\section{Association of high perceivedstress with socio- demographic characteristics of the respondents}

Table 3 shows the association between stress and socio-demographic characteristics of the respondents based on the comparison of 195 subjects with low/Moderate stress and 393 subjects with high stress. The high-stress level was more among the male respondents $(69.8 \%)$ compared to the female respondents and the difference was statistically significant $\left(\mathrm{X}^{2}=8.506\right.$ $p=0.029$ ). Additionally, a greater proportion of respondents with no previous history of psychological disorders had higher stress levels when compared to respondents with a previous history of psychological disorders. The difference was also statistically significant $\left(X^{2}=16.183 p=0.001\right)$.

Similarly more respondents who were not satisfied with the support they received from the government during the pandemic $(69.9 \%)$ had higher stress levels than those satisfied. The difference was statistically significant $\left(\mathrm{X}^{2}=\right.$ 11.43. $\mathrm{p}<0.001)$. A significant proportion (70.1\%) of the Health workers had high-stress levels than the Non-Health workers $(56.6 \%)\left(\mathrm{X}^{2}=\right.$ $10.605 p=0.001)$. Lastly, more of the married respondents had more high-stress levels than the singles and separated $\left(\mathrm{X}^{2}=6.242 \mathrm{p}=0.044\right)$

The socio-demographic and psychological variable variables independently associated with the grade of stress level by logistic regression analysis

Table 4 shows the results of logistic regression analysis with a $95 \%$ confidence interval using a stepwise method to explore the factors independently associated with high-stress levels. The socio-demographic variables were entered as independent variables and the highstress level was entered as the dependent variable. The result revealed that respondents who were not satisfied with the support they received from the government during the pandemic compared had three times high stress levels than respondents who were satisfied with the support received from the government $[\mathrm{AOR}=3.228,(\mathrm{CI}=1.771-5.886)]$. Furthermore, the odd of the high stress level was onefold increased among male respondents than female respondents $[\mathrm{AOR}=1.08 \mathrm{CI}=(1.410-6.215)$.

\section{DISCUSSION}

The study determined the stress level and related factors among essential workers in Ekiti State, Nigeria during the COVID-19 lockdown. The male predominance observed among the essential workers in this study may result from the inclusion of security officers, and other professions who are predominantly males.

A significant proportion of the respondents was not satisfied with the government policy and their institutional support for essential workers during the COVID-19 lockdown despite the well-drafted relief packages and the palliatives claims by the government and various institutions. This may largely be due to the lack of proper implementation and some observed haphazard 
manner of the distribution with very weak evidence that people got these relief packages and palliatives (19). The essential workers complained mainly about lack of finance, lack of adequate information and challenge with movement. These observations may reflect the poor resources/preparations available to the needs of essential workers (20). The effect of satisfaction of the employee on their mental health cannot be overemphasized during the pandemic (21).

The prevalence of perceived high stress among essential workers in this study was $65.8 \%$, Health workers and Non-Health workers had a prevalence of $70.1 \%$ and $56.5 \%$ respectively. The prevalence is high both among health and nonhealth workers. This high prevalence is comparable to findings from previous studies globally $(22,23)$. These observations are not unexpected during this period because of the negative socioeconomic impact and other significant changes of the COVID-19 lockdown.Although research work predating the COVID-19 pandemic had established that the stress level among healthcare workers was high (24)

The factors among respondents associate with high Perceived stress were respondents with no previous history of psychological illness, nonsatisfaction with the government support, being a male, married, and Health workers. Increased levels of stress in people without previous history of the psychological disorder may be due to a lack of mental resilience to cope with the psychological effect of the pandemic. Some earlier studies have identified varying stressors to healthcare workers and various mechanisms for coping $(25,26)$. These coping mechanisms include amongst others positive thinking styles, escape-related coping styles, and control-related or direct coping styles. These interventions together with organizational strategies aimed at improving levels of coping may ultimately reduce the effect of occupational-related stress.

In the same vein, essential workers having regular contact with mental health experts before the pandemic might have been taught adaptive coping strategies which are of ultimate benefit during this period. Also, respondents who were not satisfied with the government support may have may be faced with poor remuneration and lack of basic socio-economic power to cope with the associated stress of the lockdown, and an added stress of being a frontline worker during the pandemic. The government also may have a major role to play to increase the level of satisfaction and acceptability of their programs and policies. This is very important because, there were many relief packages and policies by the Nigerian government during the lockdown, however, a significant proportion of the respondents still had high stress.

A higher level of perceived stress was observed among male respondents in this study, this is at variance with an earlier report of high level of perceived stress among female health workers (21). In addition, the male respondents in this present study were likely to have more responsibilities like being married as evident by the significant proportion and also saddled with other socio-economic responsibilities which might be difficult to meet during the COVID-19 lockdown given that they also need to perform their COVID-19 essential duty roles. In addition, male essential workers services may have an assignment with longer hours during the COVID19 lockdown compared to their female counterparts. Apportioning greater tasks and more strenuous, more stressful, and more laborious work to males is a cultural belief in Africa signifying as a sign of their strength over females (27).

Marriage is both a protective and risk factor for psychological illness, respondents who were married during the COVID 19 lockdown may have high stress because of the negative socio-economic impact of the lockdown. Married respondents have responsibilities towards the spouse and children coupled with performing their duties during the lockdown. Besides more partners might have lost their job during this period. Lower socioeconomic status is associated with more chronic stress and less marital satisfaction (28)

Health workers are the front-line fighters against COVID 19. They have the risk of infection, infecting others including their family members, and death. The immediate and sustained effect of global infectious disease outbreaks on the mental health of health care workers (HCWs) is incontestable. Mental health problems observed among Health Care Workers during COVID-19 include sleep disturbance, anxiety, and fear of contagion. A study from China found that a substantial number of Health Care Workers who treated COVID-19 patients suffered from depression, anxiety, insomnia, and distress (29).

Poor transportation, poor funding, and hearing COVID 19 related news were the main source of stressors for essential workers during the COVID 19 lockdown. Transportation was a 
major source of worry to most of the respondents during the pandemic; some of the mobile respondents may not be financially buoyant to fuel their cars, besides, most filling stations and automobile part dealers were under lock and key which increased the difficulty of getting fuel and spare parts when the cars need repair. The government and many organizations could not also provide alternative means of transportation to the essential workers. Respondents who were not mobile also faced high-cost transportation from commercial drivers.

Funding is a major determinant of the success of any program. Despite the significant amount claimed to have been spent by the government to cushion the negative COVID 19, a significant proportion of the respondent still perceived funding as a stressor and as well as non-satisfaction with the support received by the government during this period. This may result from ineffective disbursement policy from the government to the essential workers,

During the COVID 19 lockdown, most of the COVID-related news may likely generate anxiety among the respondents. The prominent news during this period of daily increase in numbers of cases, the nationwide spread of the virus, inadequate facility in the isolation centers, overstretching our health sector, inadequate definitive treatment, and reported numbers of death as a result of the virus may be stressful

Limitations: A self-administered questionnaire is used with the assumption that respondents will answer each question truthfully. This is subject to reporting bias. Additionally, this study was restricted to the respondents who had smartphones and are literate which could have excluded some potential participants. Poor internet access might have limited access and response to the survey. Despite these limitations, this study was able to establish some important predictors/determinants of stress among essential workers in Ekiti state which could be the targets for interventions by relevant stakeholders. In addition, we also included other essential workers aside from health workers thus allowing for the possibility of capturing a wider view on the subject. Furthermore, this is the first report on the subject from our study locality.

\section{CONCLUSION}

The COVID-19 Pandemic has caused a high level of perceived stress, among the essential workers in Ekiti StateNigeria and this is in keeping with other studies. Poor transportation, poor funding, and hearing COVID 19 related news were the main source of stressors for essential workers during the COVID 19 lockdown while the associated factors of high stress among respondents were respondents with no previous history of psychological illness, nonsatisfaction with the government support, being a male, married, and Health workers. The mental health of the essential workers should be adequately considered to improve the overall productivity of the workers.

\section{Recommendations}

(1) The modes of information dissemination and implementation of government policies may need to be improved and be more inclusive. Common sources of stress identified in this study and related studies (finance, hearing of COVID 19 related news, access to essential food items, and transportation challenges) should be considered by the government and relevant stakeholders.

(2) There should be provision for regular mental health assessment and teaching of adaptive coping strategies for essential workers, both as government directive and organizational processes. Also, all workers including essential workers should be adequately remunerated to include special allowances for the prevailing situation. Furthermore, there should be provision for relaxation within the work environment.

(3) Dissemination of information should be without ambiguously and handled by an expert during the pandemic. Essential workers should also have uninterrupted to the right information to reduce fake information associated with the virus

(4) There should be a collaborative effort between the government and all the workers in other to reduce the psychological stress associated with the pandemic.

Funding: This research is self-sponsored

Conflicts of Interest: The authors have none to declare

Acknowledgments: I want to acknowledge various Heads of Departments and all the Essential Workers during the COVID 19 lockdown in 2020 for the support during the study. 


\section{REFERENCES}

1. Bansal $P$, Bingemann TA, Greenhawt $M$, Mosnaim G, Nanda A, Oppenheimer J, et al. Clinician wellness during the COVID-19 pandemic: extraordinary times and unusual challenges for the allergist/immunologist. The Journal of Allergy and Clinical Immunology: In Practice. 2020;8(6):1781-90.

2. Al-Hanawi MK, Mwale ML, Alshareef $\mathrm{N}$, Qattan AM, Angawi K, Almubark R, et al. Psychological distress amongst health workers and the general public during the COVID-19 pandemic in Saudi Arabia. Risk management and healthcare policy. 2020;13:733-742.

3. Del Rio C, Malani PN. COVID-19-new insights on a rapidly changing epidemic. Jama. 2020;323(14):1339-40.

4. Nas FS, Ali M, Azu LM, Abdallah MS, Yusuf SF. Epidemiology of novel COVID-19 in Nigeria. Microbes and Infectious Diseases. 2020;1(2):4956.

5. Roy RK, Roy DK, Goit RK. Substance Abuse Among Medical Students-A Survey in a Medical College in Nepal. Journal of Nepalgunj Medical College. 2018;16(1):71-5.

6. Kim Y, Calzada EJ, Barajas-Gonzalez RG, Huang K-Y, Brotman LM, Castro A, et al. The role of authoritative and authoritarian parenting in the early academic achievement of Latino students. Journal of Educational Psychology. 2018;110(1):119.

7. Felice C, Di Tanna GL, Zanus G, Grossi U. Impact of COVID-19 outbreak on healthcare workers in Italy: results from a national e-survey. Journal of community health. 2020 Aug;45(4):675-83

8. Cooper A-P, Jormanainen I, Shipepe A, Sutinen E. Faith communities online: Christian churches' reactions to the COVID-19 outbreak. International Journal of Web-Based Communities. 2021;17(2):99-119.

9. Bingemann T, Sharma H, Nanda A, Khan DA, Markovics S, Sussman J, et al. AAAAI Work Group Report: physician wellness in allergy and immunology. The Journal of Allergy and Clinical Immunology. 2020;8(4):1224-9.

10. Biswas P, Chatterjee S. Hand hygiene compliance among doctors in a tertiary care hospital of India. The Indian Journal of Pediatrics. 2014;81(9):967-8.

11. Luan $\mathrm{R}, \mathrm{Pu} \mathrm{W}$, Dai L, Yang $\mathrm{R}$, Wang $\mathrm{P}$. Comparison of psychological stress levels and associated factors among healthcare workers, frontline workers, and the general public during the novel coronavirus pandemic. Frontiers in Psychiatry. 2020;11: 583971-583976

12. Khasne RW, Dhakulkar BS, Mahajan HC, Kulkarni AP. Burnout among healthcare workers during COVID-19 pandemic in India: results of a questionnaire-based survey. Indian Journal of Critical Care Medicine: Peer-reviewed, Official Publication of Indian Society of Critical Care
Medicine. 2020;24(8):664-671.

13. Omilusi M, Isaac AA. From 200 Dollars to 50 Dollars: The Political Economy of Nigerian Workers' Retrogressive Living Wage in Four Decades. I nternational Journal of Research in Business and Management; 2020;2(1); 1-11

14. Ganiyu KA, Ekwueme MC, and Ebiware-Otubo A. Completeness and Legibility of Prescriptions and Prescribing Practice at Two Health Centres on Wilberforce Island, Bayelsa State, Nigeria. Journal of Basic and Social Pharmacy Research, 2020;1(4):24-32.

15. Shapiro AJ, Heath NL, Carsley D. Pilot evaluation of the feasibility and acceptability of StressOFF Strategies: a single-session schoolbased stress management program for adolescents. Advances in School Mental Health Promotion. 2016;9(1):12-28.

16. Ojobo HI, Malaysia UT, Malaysia UT, Malaysia UT. Validating the Measures of Perceived Restorativeness in Obudu Mountain Resort, Cross River State, Nigeria. Open Journal of Social Sciences. 2014;2(11):1-6

17. James BO, Thomas IF, Omoaregba JO, Okogbenin EO, Okonoda KM, Ibrahim AW, Salihu AS, Oshodi YO, Orovwigho A, Odinka PC, Eze GO, Onyebueke GC, Aweh BE. Psychosocial correlates of perceived stress among undergraduate medical students in Nigeria. International Journal of Medical Education. 2017; 26;(8):382-388.

1. 18 Ossai EN, Alo AT, Onwe BC, Okoro DO, Ezeagu NE, Ogbonnaya LU. Prevalence and predictors of perceived stress: A study among medical students of Ebonyi State University Abakaliki, Nigeria. Asian Journal of Advanced Research and Reports. 2019; 4:1-9.

18. Ufua DE, Osabuohien E, Ogbari ME, Falola HO, Okoh EE, Lakhani A. Re-strategising government palliative support systems in tackling the challenges of COVID-19 Lockdown in Lagos State, Nigeria. Global Journal of Flexible Systems Management. 2021 Jun;22(1):19-32.

19. Shan C, Tang D Y. The value of employee satisfaction in disastrous times: Evidence from COVID-19. Available at SSRN 3560919. 2020. $1-42$

20. Lai J, Ma S, Wang Y, Cai Z, Hu J, Wei N, et al. Factors associated with mental health outcomes among health care workers exposed to coronavirus disease 2019. JAMA network open. 2020;3(3):203976-2033988

21. Si M-Y, Su X-Y, Jiang Y, Wang W-J, Gu X-F, Ma L, et al. Psychological impact of COVID-19 on medical care workers in China. Infectious diseases of poverty. 2020;9(1):1-13.

22. Aiyer A, Surani S, Varon J, Ali M, Sunesara S. Covid-19 Anxiety and Stress Survey (Cass) in Healthcare Workers Due To Coronavirus Disease 2019. Chest. 2020;158(4):313-315

23. Sathiya N, Ruwaidha R, Nusrath FS, Fathima F, 
Gomathy T, Shailendra HK. Perceived stress levels and their sources among doctors and nurses working in a tertiary care teaching hospital, Kancheepuram, Tamil Nadu. Ntl J Community Med. 2016;7(7):603-8.

24. Lindo J, LaGrenade J, McCaw-Binns A, Eldemire-Shearer D. Health status and health maintenance practices among doctors and nurses at two hospitals in Jamaica. West Indian medical journal. 2009;58(6).539-546

25. Lindo J, McCaw-Binns A, LaGrenade J, Jackson M, Eldermire-Shearer D. Mental well-being of doctors and nurses in two hospitals in Kingston, Jamaica. West Indian Med J. 2006;55(3):153-9.
26. Gettler LT. Direct male care and hominin evolution: why male-child interaction is more than a nice social idea. American Anthropologist. 2010;112 (1):7-21.

27. Turliuc, M. N. Candel, O. S. 2021. Not all in the same boat. Socioeconomic differences in marital stress and satisfaction during the Covid-19 pandemic. Frontiers in Psychology, 2021;12.111

28. Lai, J., Ma, S., Wang, Y., Cai, Z., Hu, J., Wei, N., Wu, J., Du, H., Chen, T. Li, R. Factors associated with mental health outcomes among health care workers exposed to coronavirus disease 2019. JAMA network open, 2020; 3, 203976-203976.

How to cite this article:

Falade J., Oshatimi A.M., Oyebanji A.H., Babatola A.O., Fadare J.O., Olatunya O.S., Falade O.O. High level of perceived stress among essential workers during the COVID 19 lockdown in a Nigerian state. Research Journal of Health Sciences, 2021, 9(4): 344-358 
Table 1A: socio - demographics characteristics of the respondents

\begin{tabular}{|c|c|c|}
\hline Variable & Frequency $(n=588)$ & Percentage (\%) \\
\hline \multicolumn{3}{|l|}{ Age } \\
\hline$=35$ years & 330 & 56.1 \\
\hline$>$ 36years & 258 & 43.9 \\
\hline \multicolumn{3}{|l|}{ Gender } \\
\hline Female & 191 & 32.5 \\
\hline Male & 397 & 67.5 \\
\hline \multicolumn{3}{|l|}{ Religion } \\
\hline Christianity & 504 & 85.7 \\
\hline Islam & 84 & 14.3 \\
\hline \multicolumn{3}{|l|}{ Occupation } \\
\hline Health worker & 402 & 68.4 \\
\hline Non-health worker & 186 & 31.6 \\
\hline \multicolumn{3}{|l|}{ Marital status } \\
\hline Single & 156 & 26.5 \\
\hline Married & 423 & 71.9 \\
\hline Separated & 9 & 1.5 \\
\hline \multicolumn{3}{|l|}{ Family type } \\
\hline Monogamous & 546 & 92.9 \\
\hline Polygamous & 42 & 7.1 \\
\hline \multicolumn{3}{|l|}{ Tribe } \\
\hline Yoruba & 485 & 82.5 \\
\hline Hausa & 84 & 14.3 \\
\hline Igbo & 19 & 3.2 \\
\hline \multicolumn{3}{|l|}{ Salary } \\
\hline$=250,000$ & 438 & 74.5 \\
\hline$>250,000$ & 150 & 25.5 \\
\hline
\end{tabular}


Table 1 B Psychological Variable among Respondents

\begin{tabular}{lll}
\hline Variable & frequency & percentage \\
\hline $\begin{array}{l}\text { Previous history of } \\
\text { psychological disorder }\end{array}$ & & \\
Yes & 136 & 23.1 \\
No & 452 & 76.9 \\
& & \\
Family history of & & \\
psychological disorder & & 5.3 \\
Yes & 31 & 94.7 \\
No & 557 & \\
& & \\
$\begin{array}{l}\text { Satisfaction with } \\
\text { government }\end{array}$ & & \\
$\begin{array}{l}\text { Not satisfied } \\
\text { Satisfied }\end{array}$ & 428 & 72.8 \\
& 160 & 27.2 \\
$\begin{array}{l}\text { Satisfaction with } \\
\text { organization }\end{array}$ & & \\
$\begin{array}{l}\text { Not satisfied } \\
\text { Satisfied }\end{array}$ & 437 & 80.4 \\
\hline
\end{tabular}

Table 2: Sources of Stressor among essential workers during the COVID-19 lockdown

\begin{tabular}{lll}
\hline Variable & Frequency & Percentage \\
\hline Source of stress during the pandemic & & \\
Poor Finance & 324 & 55.1 \\
Illness & 72 & 12.1 \\
Death of a close relative & 45 & 7.7 \\
Hearing of COVID related News & 279 & 47.4 \\
Sickness of other family members & 147 & 25.0 \\
Sick or affected spouse & 78 & 13.3 \\
Affected or death of colleagues at work & 90 & 15.3 \\
Fear of infecting the children & 68 & 11.6 \\
Restriction to movement/inadequate \\
transportation
\end{tabular}


Table 3A: Association of socio-demographic characteristics of the respondents with stress

\begin{tabular}{|c|c|c|c|}
\hline \multirow[t]{2}{*}{ Variable } & \multicolumn{2}{|c|}{ Stress category } & \multirow[t]{2}{*}{ Pvalue } \\
\hline & $\begin{array}{l}\text { Low/Moderate } \\
\text { stress } n(\%)\end{array}$ & $\begin{array}{l}\text { High stress } \\
\mathrm{n}(\%)\end{array}$ & \\
\hline \multicolumn{4}{|l|}{ Age } \\
\hline$=35$ years & $123(37.3)$ & $207(62.7)$ & 0.074 \\
\hline$>36$ years & $78(30.2)$ & $180(69.8)$ & \\
\hline \multicolumn{4}{|l|}{ Gender } \\
\hline Female & $81(42.40$ & $110(57.6)$ & 0.004 \\
\hline Male & $120(30.2)$ & $277(69.8)$ & \\
\hline \multicolumn{4}{|l|}{ Religion } \\
\hline Christianity & 171(33.9) & $333(66.1)$ & 0.749 \\
\hline Islam(Muslims) & $30(35.7)$ & $54(64.3)$ & \\
\hline \multicolumn{4}{|l|}{ Occupation } \\
\hline Health worker & $120(29.9)$ & $282(70.1)$ & 0.001 \\
\hline Nonhealth worker & $81(43.5)$ & $105(56.5)$ & \\
\hline \multicolumn{4}{|l|}{ Marital status } \\
\hline Single & $66(42.3)$ & $90(57.7)$ & 0.044 \\
\hline Married & $132(31.2)$ & $291(68.8)$ & \\
\hline Separated & $3(33.32)$ & $6(66.7)$ & \\
\hline \multicolumn{4}{|l|}{ Family type } \\
\hline Monogamous & 189(34.6) & $357(65.4)$ & 0.426 \\
\hline Polygamous & $12(28.6)$ & $30(71.4)$ & \\
\hline \multicolumn{4}{|l|}{ Tribe } \\
\hline Yoruba & $173(35.7)$ & $312(64.3)$ & 0.158 \\
\hline Hausa & $21(25.0)$ & $63(75.0)$ & \\
\hline Igbo & $7(36.2)$ & $12(63.2)$ & \\
\hline \multicolumn{4}{|l|}{ Salary } \\
\hline$=250,000$ & $145(33.1)$ & 293(66.9) & 0.346 \\
\hline$>250,000$ & $56(37.8)$ & $94(62.4)$ & \\
\hline
\end{tabular}


Table 3B Association of Psychological variable of the respondents with stress level

\begin{tabular}{|c|c|c|c|}
\hline \multirow[t]{2}{*}{ Variable } & \multicolumn{2}{|c|}{ Stress Category } & \multirow[t]{2}{*}{ P-value } \\
\hline & $\begin{array}{l}\text { Low/Moderate } \\
\text { stress n(\%) }\end{array}$ & $\begin{array}{l}\text { High stress } \\
\text { n }(\%)\end{array}$ & \\
\hline \multicolumn{4}{|c|}{$\begin{array}{l}\text { Previous history } \\
\text { of psychological } \\
\text { disorder }\end{array}$} \\
\hline Yes & $66(48.5)$ & $70(51.3)$ & $<0.001$ \\
\hline No & $135(29.9)$ & $317(70.1)$ & \\
\hline \multicolumn{4}{|c|}{$\begin{array}{l}\text { Family history of } \\
\text { psychological } \\
\text { disorder }\end{array}$} \\
\hline Yes & $8(25.8)$ & $23(74.2)$ & 0.321 \\
\hline No & $193(34.6)$ & $364(65.4)$ & \\
\hline \multicolumn{4}{|c|}{$\begin{array}{l}\text { Satisfaction from } \\
\text { government }\end{array}$} \\
\hline Not satisfied & $129(30.1)$ & 299(69.9) & 0.001 \\
\hline Satisfied & $72(45.0)$ & $88(55.0)$ & \\
\hline \multicolumn{4}{|c|}{$\begin{array}{l}\text { Satisfaction from } \\
\text { organization }\end{array}$} \\
\hline Not satisfied & $168(35.5)$ & $305(64.5)$ & 0.167 \\
\hline Satisfied & $33(28.7)$ & $82(71.3)$ & \\
\hline
\end{tabular}


Table 4: Socio-demographic and psychological variables independently associated with grades of stress level by logistic regression

\begin{tabular}{|c|c|c|c|c|c|c|c|c|}
\hline \multirow[t]{2}{*}{ Variable } & \multirow{2}{*}{$\begin{array}{l}\text { Crude } \\
\text { OR }\end{array}$} & \multirow{2}{*}{$\begin{array}{l}\text { P- } \\
\text { value }\end{array}$} & \multicolumn{2}{|c|}{$95 \%$ CI } & \multirow{2}{*}{$\begin{array}{l}\text { Adjusted } \\
\text { OR }\end{array}$} & \multirow{2}{*}{$\begin{array}{l}P- \\
\text { value }\end{array}$} & \multicolumn{2}{|c|}{$95 \% \mathrm{CI}$} \\
\hline & & & Lower & Higher & & & Lower & Higher \\
\hline \multicolumn{9}{|c|}{$\begin{array}{l}\text { previous history of } \\
\text { psychological disorder }\end{array}$} \\
\hline Yes (ref) & 1 & & & & & & & \\
\hline No & 0.452 & 0.000 & 0.305 & 0.668 & 1.510 & 0.998 & 0.00 & - \\
\hline \multicolumn{9}{|c|}{$\begin{array}{l}\text { Satisfied with } \\
\text { government support }\end{array}$} \\
\hline Satisfied (ref) & 1 & & & & & & & \\
\hline Not satisfied & 0.527 & 0.001 & 0.363 & 0.706 & 3.228 & $<0.001$ & 1.771 & 5.886 \\
\hline \multicolumn{9}{|l|}{ Gender } \\
\hline Female(ref) & & 1 & & & & & & \\
\hline Male & & 0.004 & & & 1.085 & 0.004 & 1.410 & 6.215 \\
\hline \multicolumn{9}{|l|}{ Occupation } \\
\hline Non-health & 1 & & & & & & & \\
\hline Health & 0.552 & 0.001 & 0.385 & 0.791 & 1.035 & 0.898 & 0.614 & 1.743 \\
\hline \multicolumn{9}{|l|}{ Marital status } \\
\hline Separated(ref) & & 1 & & & & & & \\
\hline Single & & 0.444 & & & 715.2 & 0.998 & 0.00 & \\
\hline Married & & 0.047 & & & 0.591 & 0.469 & 0.142 & 2.457 \\
\hline
\end{tabular}

ref- reference point which is the variable to which others are being compared

OR- Odd ratio, CI- Confidence interval

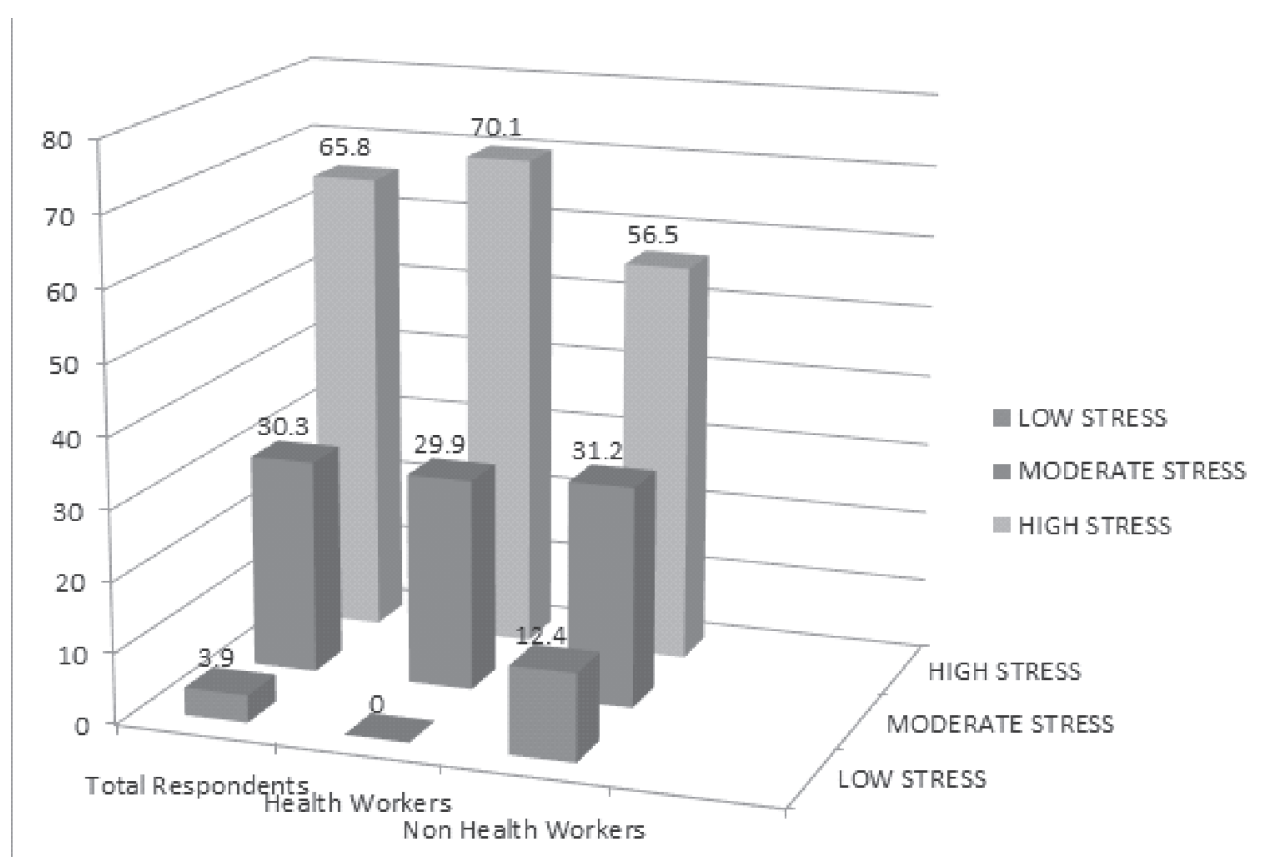

Figure 1-stress level among the total respondents, non-health workers, and health workers

Res. J. of Health Sci. Vol 9(4), October/December 2021 


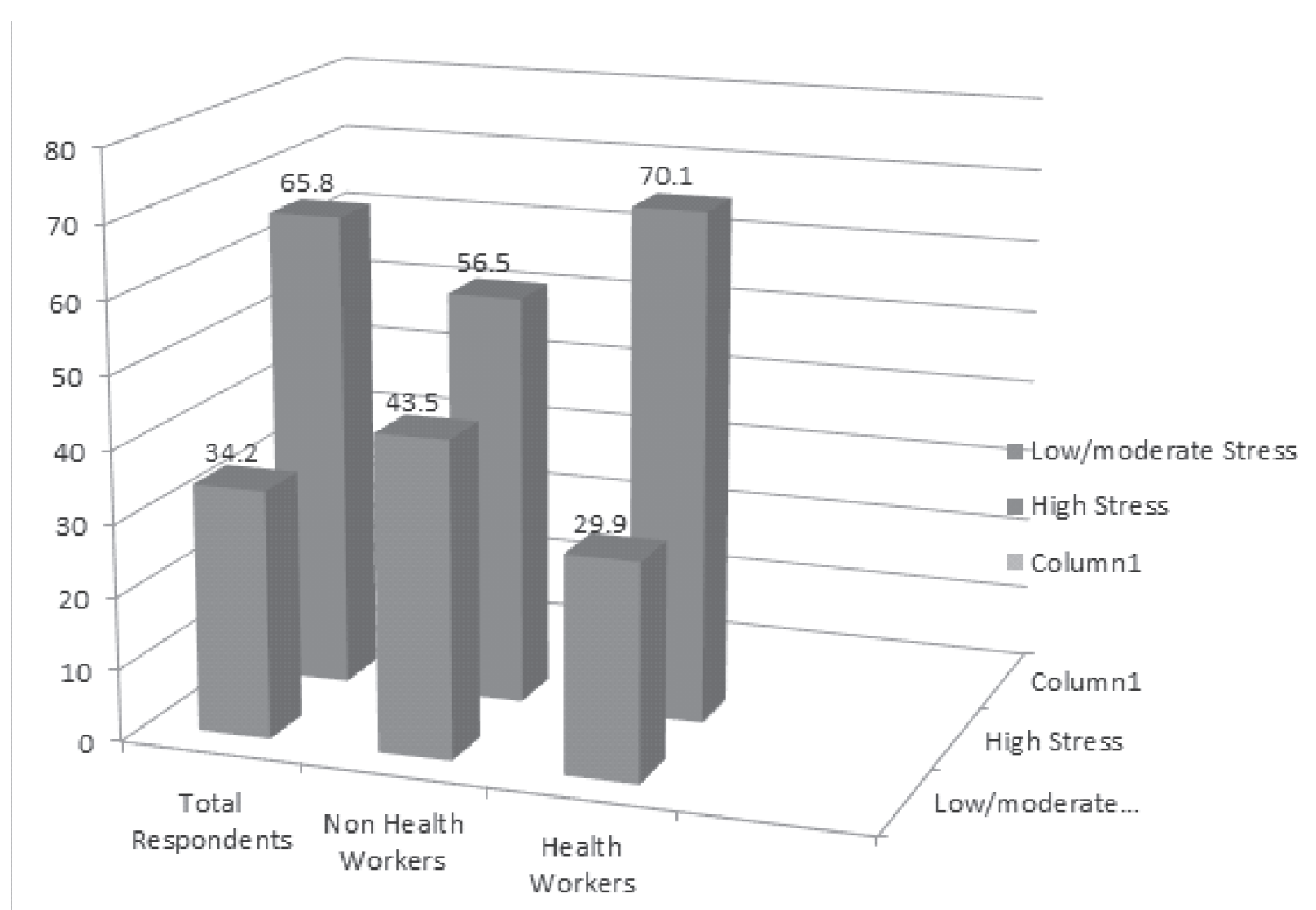

Figure 2 -stress level among the total respondents, non-health workers, and health workers 